\title{
Adenocarcinoma arising from a gastric duplication cyst: a case report and literature review
}

\author{
This article was published in the following Dove Press journal: \\ International Medical Case Reports Journal \\ 6 November 2017 \\ Number of times this article has been viewed
}

\author{
Maheeba Abdulla Mohamed \\ Abdulla' \\ Mahmood Al Saeed' \\ Safa Ameer Alshaikh² \\ Umesh J Nabar ${ }^{3}$ \\ 'Department of Internal Medicine, \\ ${ }^{2}$ Department of Pathology, \\ ${ }^{3}$ Department of Radiology, Salmaniya \\ Medical Complex, Manama, The \\ Kingdom of Bahrain
}

Introduction: Alimentary tract cystic duplication is a rare congenital anomaly predominantly affecting females, and diagnosed mostly in the early years of life.

Case report: We present here a case of a 51-year-old man presenting with a 2-day history of melena. Gastroscopy showed fresh blood, as well as a mass lesion and cavity at the fundus. Biopsies of the mass edge reported the occurrence of moderately differentiated adenocarcinoma and mild chronic gastritis. Computed tomography imaging showed a $5.1 \times 6.5 \mathrm{~cm}$ cystic mass in the gastric greater curvature. The patient received six cycles of epirubicin, capecitabine, and oxaliplatin, followed by uncomplicated total gastrectomy.

Literature review: Data from all 11 reports of similar cases were reviewed and pooled. The result shows male predominance and variable symptoms, as well as a wide age range (25-76 years) at presentation. The cysts are commonly located along the greater curvature and are unilocular. Surgery was the treatment in most cases.

Conclusion: Alimentary tract cystic duplication is rare and may predispose to malignancy. Early diagnosis and prompt surgical intervention is important for the best outcome.

Keywords: gastric duplication cyst, gastric mass, adenocarcinoma, cystic duplication, alimentary tract cystic duplication

\section{Introduction}

Duplication of the alimentary tract is a rare congenital anomaly, with an incidence of 1 in 4,500 live births. ${ }^{1}$ Two forms of duplication have been reported, namely, tubular and cystic. The tubular form communicates with the normal intestinal tract, while the cystic form is separate from it. ${ }^{1,2}$ Furthermore, most enteric duplication cysts are diagnosed during the first year of life, and about $70 \%$ of cases are identified by the age of 12 years. ${ }^{3}$ In 1961, Potter reported 2 cases in $>9,000$ fetal and neonatal autopsies. ${ }^{4}$ They may be slightly more common in males. ${ }^{5}$ The most common location is the ileum $(35 \%)$, while the least common site is the stomach $(2 \%-9 \%)$. Although very rare, carcinoma can arise from a gastric duplication cyst (GDC). Adenocarcinoma rarely arises from a GDC and, to our knowledge, only 11 cases (in the English language literature) have been reported to date (Table 1). ${ }^{6-16}$ Numerous other cases were reported in languages other than English. ${ }^{17-19}$ Nonetheless, there can be no argument that carcinomas arising from a GDC are especially rare. We are reporting, herein, a case of a 51-year-old man who, along with a duplication of the alimentary tract affecting the stomach, presented with melena, and upon further investigation, a well-differentiated adenocarcinoma was detected. In addition, we review the diagnosis and treatment of similar patients reported in the literature.
Correspondence: Maheeba Abdulla Mohamed Abdulla

Department of Internal Medicine, Salmaniya Medical Complex, PO Box 12, Manama, The Kingdom of Bahrain Email amaheeba@hotmail.com 
Table I Summary of case studies reporting adenocarcinoma arising in GDC

\begin{tabular}{|c|c|c|c|c|c|}
\hline References & Age (years), sex & Symptoms & Location & Size & Note \\
\hline $\begin{array}{l}\text { Yamasaki et al, } \\
2016^{6}\end{array}$ & 42 , female & No & $\begin{array}{l}\text { Adjacent to the } \\
\text { greater curvature of } \\
\text { stomach }\end{array}$ & $\begin{array}{l}10.0 \times 9.5 \times 8.0 \mathrm{~cm} \\
\text { unilocular cystic } \\
\text { mass }\end{array}$ & $\begin{array}{l}\text { Despite complete resection, the patient } \\
\text { developed metastasis, underwent oral } \\
\text { chemotherapy (TS-I), and died } 2 \text { months } \\
\text { later. }\end{array}$ \\
\hline Liu et al, $2014^{8}$ & 28 , male & No & $\begin{array}{l}\text { Adhered to gastric } \\
\text { corpus }\end{array}$ & $10 \times 10 \mathrm{~cm}$ & $\begin{array}{l}7 \text { months after surgery (in which the cyst } \\
\text { ruptured), metastatic adenocarcinoma with } \\
\text { peritoneal carcinomatosis was diagnosed. }\end{array}$ \\
\hline Kang et al, $2014^{7}$ & 56 , male & No & $\begin{array}{l}\text { Along the greater } \\
\text { curvature of the } \\
\text { stomach }\end{array}$ & $\begin{array}{l}5.5 \times 3.5 \times 2.5 \mathrm{~cm} \\
\text { unilocular cyst }\end{array}$ & $\begin{array}{l}\text { Patient underwent a wedge resection } \\
\text { to remove the lesion. Adenocarcinoma } \\
\text { showing invasion to the proper muscle } \\
\text { layer of the cyst was observed. }\end{array}$ \\
\hline Shin et al, $2014^{9}$ & 52 , male & $\begin{array}{l}\text { Abdominal } \\
\text { pain }\end{array}$ & Peritoneum & $\begin{array}{l}4 \times 3 \times 3 \mathrm{~cm} \\
\text { unilocular cyst }\end{array}$ & $\begin{array}{l}\text { Entire cyst was excised. Findings were } \\
\text { consistent with an adenocarcinoma that } \\
\text { had arisen from the intestinal duplication } \\
\text { cyst. }\end{array}$ \\
\hline Blank et al, $2012^{10}$ & 5I, male & No & Ileal mesentery & $4 \times 10 \mathrm{~cm}$ & $\begin{array}{l}\text { An en bloc resection was done. } \mathrm{H}-\mathrm{E} \\
\text { staining revealed poorly differentiated } \\
\text { invasive adenocarcinoma (intestinal type). }\end{array}$ \\
\hline $\begin{array}{l}\text { Zheng and Jing, } \\
2012^{11}\end{array}$ & 25 , male & No & $\begin{array}{l}\text { The greater curvature } \\
\text { of the stomach }\end{array}$ & Not found & $\begin{array}{l}\text { Resection with total gastrectomy and } \\
\text { regional lymphadenectomy were done. This } \\
\text { is the youngest patient reported. }\end{array}$ \\
\hline Jiang et al, $201 \mathrm{I}^{12}$ & 76 , male & $\begin{array}{l}\text { Incidentally } \\
\text { found } \\
\text { perigastric } \\
\text { mass }\end{array}$ & $\begin{array}{l}\text { Below the } \\
\text { gastroesophageal } \\
\text { junction }\end{array}$ & $4 \times 4 \mathrm{~cm}$ & $\begin{array}{l}\text { Preoperative diagnosis was a GIST, and } \\
\text { surgical excision was performed. The } \\
\text { patient had an uneventful recovery. }\end{array}$ \\
\hline $\begin{array}{l}\text { Fukumoto et al, } \\
2008^{13}\end{array}$ & 50, male & $\begin{array}{l}\text { Persistent } \\
\text { vomiting due } \\
\text { to pyloric } \\
\text { stenosis }\end{array}$ & $\begin{array}{l}\text { Mass on greater } \\
\text { curvature of upper } \\
\text { gastric corpus and } \\
\text { mass adjacent to the } \\
\text { bulbus }\end{array}$ & $\begin{array}{l}\text { Masses of sizes } \\
2 \mathrm{~cm} \text { and } 3 \mathrm{~cm}\end{array}$ & $\begin{array}{l}\text { Histological findings showed } \\
\text { adenocarcinoma in the anal duplication } \\
\text { cyst wall. A pancreatoduodenectomy was } \\
\text { performed } 9 \text { days after initial surgery. } \\
\text { Patient died I } 4 \text { months later of local } \\
\text { recurrence and multiple liver metastases. }\end{array}$ \\
\hline $\begin{array}{l}\text { Kuraoka et al, } \\
2004^{14}\end{array}$ & 40, male & $\begin{array}{l}\text { Fever and } \\
\text { back pain }\end{array}$ & $\begin{array}{l}\text { Between stomach and } \\
\text { spleen }\end{array}$ & $\begin{array}{l}7 \mathrm{~cm} \text { in diameter } \\
\text { and unilocular }\end{array}$ & $\begin{array}{l}\text { Tubular adenocarcinoma was discovered, } \\
\text { wherein the cyst had adhered I month } \\
\text { after cystectomy. }\end{array}$ \\
\hline $\begin{array}{l}\text { Coit and Mies, } \\
1992^{15}\end{array}$ & 72 , female & No & $\begin{array}{l}\text { Adjacent to greater } \\
\text { curvature of stomach }\end{array}$ & $\begin{array}{l}3.2 \mathrm{~cm} \text { in } \\
\text { diameter }\end{array}$ & $\begin{array}{l}\text { Adenocarcinoma believed to have arisen } \\
\text { in the GDC was identified, and the } \\
\text { patient underwent a radical distal subtotal } \\
\text { gastrectomy with Billroth I reconstruction. }\end{array}$ \\
\hline Mayo et al, $1955^{16}$ & 64 , female & $\begin{array}{l}\text { Weakness, } \\
\text { anorexia, and } \\
\text { malaise }\end{array}$ & $\begin{array}{l}\text { Distal end of antrum } \\
\text { of the stomach }\end{array}$ & $6 \mathrm{~cm}$ in diameter & $\begin{array}{l}\text { Carcinoma had developed, but patient } \\
\text { recovered after radical subtotal gastric } \\
\text { resection. }\end{array}$ \\
\hline
\end{tabular}

Abbreviations: GDC, gastric duplication cyst; GIST, gastrointestinal stromal tumor; H-E, hematoxylin and eosin; TS, titanium silicate; yrs, years.

\section{Case report}

A 51-year-old man presented to the Accident and Emergency Department of Salmaniya Medical Complex with a 2-day history of melena. There was no past medical history of note, no alcohol intake, and he was not on any medications. The patient stopped smoking 10 years prior to admission. There was a first-degree family history of colorectal cancer.

Upon investigation, a gastroscopy revealed fresh blood and clots in the fundus of the stomach. A mass lesion and cavity were seen along the greater curvature of the stomach during retroflexed examination of the fundus. The cavity contained an ulcerated area with clots (Figure 1). Biopsies of the mass in the cavity showed normal gastric mucosa with moderately differentiated adenocarcinoma and mild chronic gastritis (Figure 2). Computed tomography (CT) with contrast of the chest, abdomen, and pelvis demonstrated a $5.1 \times 6.5 \mathrm{~cm}$ cystic mass in the greater curvature of the stomach (Figure 3). The cyst had a $6 \mathrm{~mm}$ thickened wall, with a septum dividing it into 2 parts. Hematoxylin and eosin (H-E) staining revealed a cyst lined by benign epithelial lining (Figure 4). 

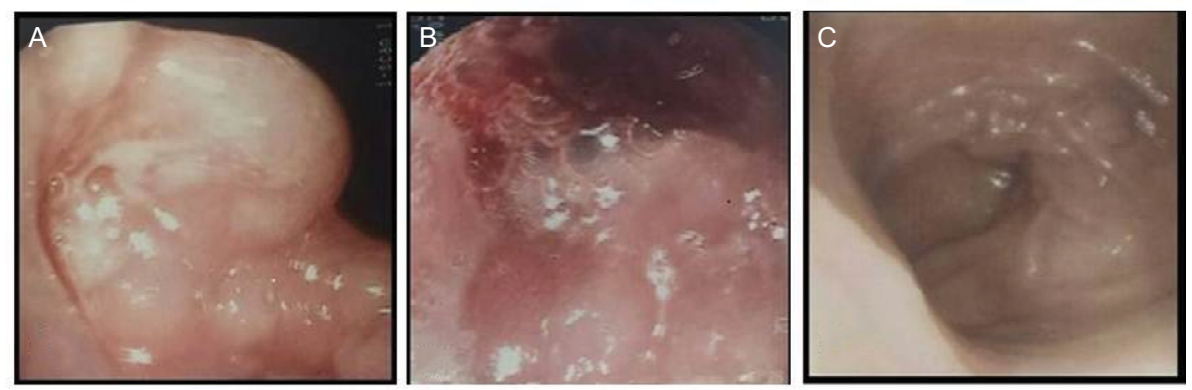

Figure I Representative endoscopic images.

Notes: (A) Image depicts a mass lesion with cavity opening observed in the fundus. (B) The cavity contained marginal ulcers with fresh and clotted blood. (C) An image of normal antrum.
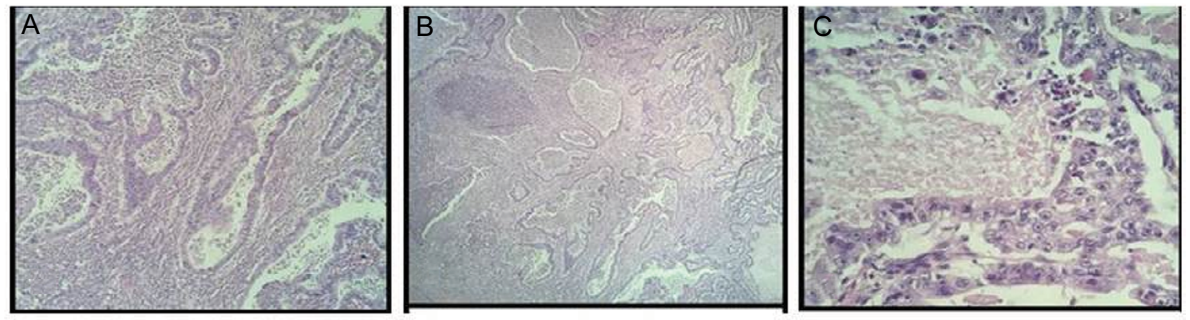

Figure 2 Histology images of moderately differentiated adenocarcinoma.

Notes: $\mathrm{H}-\mathrm{E}$ staining depicts invasive atypical glands with central necrosis in (A) (original magnification $\times 100)$ and $(\mathbf{B})($ original magnification $\times 40)$. (C) Invasive malignant glands lined by atypical pleomorphic cells with prominent nucleoli and central necrosis can be seen (original magnification $\times 400$ ).

Abbreviation: $\mathrm{H}-\mathrm{E}$, hematoxylin and eosin.
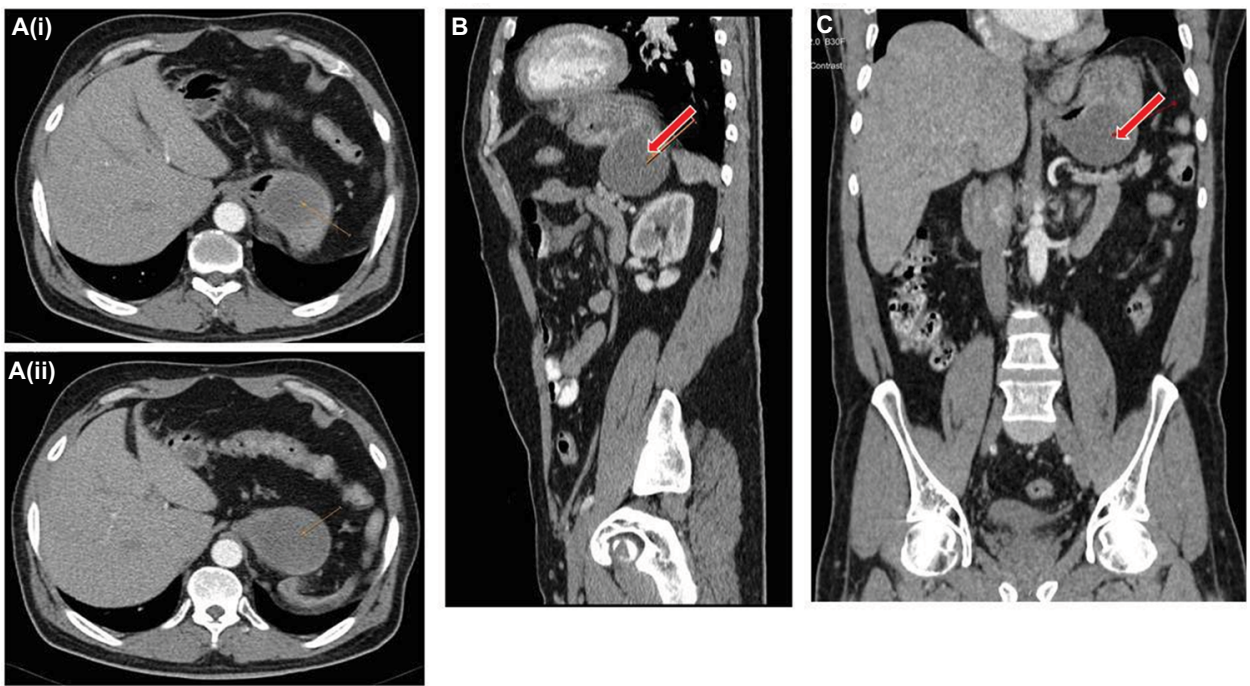

Figure 3 CT scan of the duplication cyst.

Notes: (Ai and Aii) Axial, (B) sagittal, and (C) coronal scans of the chest, abdomen, and pelvis demonstrated a well-circumscribed, round cystic mass of homogeneous density along the greater curvature of the stomach (arrows), consistent with a duplication cyst. The mass measured $5 \times 4 \mathrm{~cm}$. Abbreviation: $\mathrm{CT}$, computed tomography.

These findings fulfilled the diagnostic criteria of GDC. No metastases or other abnormalities were seen (Figure 3).

The patient declined immediate surgical resection but agreed to neoadjuvant chemotherapy followed by surgery. Six cycles of epirubicin, capecitabine, and oxaliplatin were administered over 6 months without complication. The patient achieved a partial response to chemotherapy and subsequently underwent an uncomplicated total gastrectomy. The specimen contained the full stomach with omentum and measured $18.5 \times 5 \times 4 \mathrm{~cm}$. A fungating mass measuring 

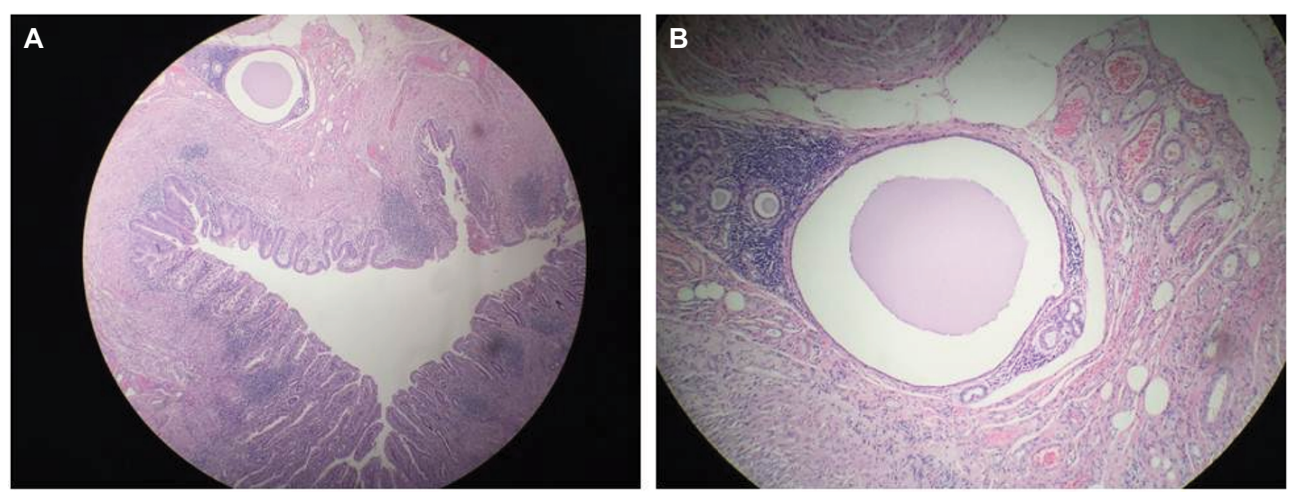

Figure 4 Histology of cyst lined by benign epithelial lining.

Note: $\mathrm{H}-\mathrm{E}$ staining shows cyst lined by benign epithelial lining, surrounded by smooth muscle fibers and chronic inflammatory cells: $(\mathbf{A})$ (original magnification $\times 10)$; and (B) higher magnification (original magnification $\times 100$ ).

Abbreviation: $\mathrm{H}-\mathrm{E}$, hematoxylin and eosin.

$5 \times 5 \times 2.5 \mathrm{~cm}$ was present in the fundus. The resection margins ranged from 2 to $13 \mathrm{~cm}$. Multiple lymph nodes of $<1 \mathrm{~cm}$ were present in the perigastric fat. Microscopic examination showed a well-differentiated adenocarcinoma with ypT2 invasion of the muscularis propria. The margins were clear of cancer. The 7th edition of the American Joint Committee on Cancer (AJCC) Tumor-Node-Metastasis (TNM) Staging Manual for the stomach was used, and the final TNM stage was ypT2 N0 Mx. Written informed consent was provided by the patient to have the case details and any accompanying images published.

\section{Literature review}

As shown in Table 1, data from all the 11 reports of similar cases collected from the English language literature were reviewed and pooled. It shows male predominance ( 8 of 11 cases were males), variable symptoms (from incidental finding to no symptoms, to some more remarkable symptoms), and a wide age range (from 25 to 76 years) at presentation. The cysts are of variable sizes (from $2.5 \mathrm{~cm}$ to $10 \mathrm{~cm}$ in diameter), commonly located along the greater curvature of the stomach, and unilocular. Surgery was the rule in most cases.

\section{Discussion}

GDCs comprise about $2 \%-9 \%$ of all alimentary tract duplications, and cystic types with no connection to the gastric lumen compromise up to $80 \%$ of these lesions. ${ }^{3}$ There is a higher male incidence of GDCs complicated with malignancy, as in our reported case and that of others (Table 1), which shows only 3 females in the pooled 11 cases. ${ }^{6-16}$ This goes with the higher male predominance of gastric cancer in most literature. Most gastric duplications are single in nature, although multiple duplications have been reported. ${ }^{6}$ GDCs are true cysts. They typically have a mucosal lining, consisting of gastric epithelium, which is surrounded by a muscularis propria. Mucosal linings consisting of ectopic pancreatic tissue or respiratory epithelium are less commonly seen. ${ }^{20}$ GDCs are typically found in the greater curvature of the stomach.

The pathogenesis for alimentary duplication cysts is a matter of controversy. It is, however, regarded as a congenital condition, and the most plausible theory consists of an aberration in the recanalization and fusion of longitudinal folds. Kim et al proposed that duplication cysts originated from the fusion of longitudinal folds, allowing the passage of a bridge of submucosa and muscle at the second and third months of intrauterine life. ${ }^{21}$ Other theories include the development of traction diverticulum, which leads to duplication cyst formation as a result of notochord adhesion and therefore a lag of the elongation process of the embryonic endoderm relative to its surrounding structures. Other potential mechanisms proposed include abortive twinning, anoxia, and persistent embryological diverticula. ${ }^{21}$

Pathologic conditions associated with alimentary tract duplication cysts include pulmonary sequestration, multicystic dysplastic kidney, and distant neoplasia. ${ }^{22}$ Malignancy arising due to GDC is also an important differential diagnosis. Adenocarcinoma is currently considered the most common histologic type of malignancy arising in GDC cases; however, neuroendocrine carcinoma and squamous cell carcinoma have also been reported. ${ }^{7}$ Table 1 represents an overview of case studies reporting adenocarcinoma arising in GDC. The risk of malignant transformation and associated complications has led to surgical excision being recommended as the standard of care for this condition. ${ }^{23}$ Open and laparoscopic excisions have been reported. Some patients have a duplication cyst that has a wall that is shared with the functional bowel. Treatment of these patients generally includes excision of only the duplicated area. ${ }^{2}$ 
Table 2 Common clinical findings in patients with duplication cysts

\begin{tabular}{ll}
\hline Adults & Children \\
\hline Asymptomatic; vague or acute abdominal & Asymptomatic; an intra- \\
pain & abdominal mass* \\
An intra-abdominal mass* & Frank or occult bleeding \\
Chronic abdominal pain & Abdominal distention \\
Symptoms of acute diverticulitis & Constipation \\
Frank or occult bleeding & Vomiting \\
At autopsy & Failure to thrive \\
During laparotomy & At autopsy \\
Symptoms of acute pancreatitis or a & During laparotomy \\
pancreatic pseudocyst mimic** & \\
\hline
\end{tabular}

Notes: These data have been collected from literature. *Due to compression of adjacent organs, such as pancreas, kidney, spleen, and adrenal gland. **As up to $10 \%$ of GDCs may contain ectopic pancreatic tissue.

Abbreviation: GDC, gastric duplication cyst.

Table 3 The essential criteria for diagnosis of a gastric duplication cyst

The wall of the cyst is contiguous with the stomach wall

The cyst is surrounded by smooth muscle, which is continuous with the muscle of the stomach wall

The cyst wall is lined by epithelium consisting of gastric or any other type of gut mucosa

Note: Data collected from literature, especially from studies Singh et al,' Hsu et al, and Kuraoka et al. ${ }^{14}$

GDCs can grow in size, leading to compression of adjacent organs, including the pancreas, kidney, spleen, or adrenal gland. ${ }^{24}$ Alimentary tract cysts are at risk for obstruction, infection, torsion, perforation, hemorrhage, and malignancy. ${ }^{1}$ Indeed, this case presented with melena (overt bleeding), which is secondary to ulcerated cancer. The possibility that this case is that of a GDC and gastric cancer arising from the gastric lumen, and not from the epithelium of the GDC, exists, and only a macroscopic image of the GDC and cancer is strongly required to prove that. Unfortunately, this image was missed in this case. Patients' symptoms at presentation are related to the pathology involved in the duplication and the age at presentation (Table 2).

The diagnosis of GDC is based on established criteria (Table 3 ). The cyst has to be intimately connected to the gastric wall and surrounded by one or more muscle layers, which are adherent to the muscle coats of the stomach. As part of the criteria, the epithelium lining is of gastric mucosa, though at times, other gut mucosa may also be found such as heterotopic intestinal or pancreatic tissues. ${ }^{22}$

Radiologically, GDCs appear classically as thick-walled cystic lesions with inner lining enhancement and occasional calcifications on both CT and magnetic resonance imaging (MRI) ${ }^{23}$ The MRI can further differentiate the type of the cyst and characterize the cystic contents..$^{22}$ The nature of the fluid in the cyst can vary with the presence of bleeding, chronic inflammation, or infection.

Endoscopic examination commonly shows a gastric mass. The overlying mucosa is often intact but, not uncommonly, can appear erythematous with or without ulceration..$^{24}$ Biopsy of the lesion is essential, and the typical changes include the following: 1) mucous membrane with a well-organized layer of smooth muscle, 2) granulomatous inflammation with denuded mucosa, and 3) foreign body giant cells. ${ }^{3}$ Endoscopic ultrasonography (EUS) can be a useful tool for diagnosing GDCs. The classic appearance is of an echogenic internal mucosal layer and a hypoechoic intermediate muscular layer. However, the yield of EUS-guided fine needle aspiration (FNA) remains uncertain as the findings are frequently indistinguishable from those of mucinous pancreatic neoplasms. ${ }^{23}$

Alimentary tract duplications are best managed by surgical resection. The conservative approach may be considered for patients with communicating GDCs and in whom both gastric lumens were patent. The use of drainage and marsupialization of the cyst has been discouraged as the unprotected mucosa of the cyst will be exposed to a greater volume of gastric contents, placing it at higher risk of ulceration. Complications such as anastomotic strictures and blind loop syndrome have been frequently reported following drainage procedures such as cystojejunostomy. ${ }^{8}$

\section{Conclusion}

GDC is a rare condition that may pose a diagnostic challenge. GDC may predispose to complications, including malignancy, as in our case. GDC should be considered when a cystic lesion is found adjoining the gastric wall. Early diagnosis and prompt surgical intervention is important for the best outcome.

\section{Disclosure}

The authors report no conflicts of interest in this work.

\section{References}

1. Singh JP, Rajdeo H, Bhuta K, Savino AJ. Gastric duplication cyst: two case reports and review of the literature. Case Rep Surg. 2013; 2013:605059.

2. Feldman Sleisenger and Fordtran's Gastrointestinal and Liver Diseases. Anatomy, Histology, Embryology and Developmental Anomalies of the Small and Large Intestine. 9th ed. (Chap. 98). Elsevier Health Sciences. 2011:1653.

3. Hsu HT, Hsing MT, Chen ML, Chen CJ. A gastric duplication cyst at the splenic hilum mimicking endometriosis clinically in a female adult. Chin Med J (Engl). 2009;122(17):2079-2080.

4. Potter EL. Pathology of the Fetus and Newborn. Arnold Edward, Chicago; 1961.

5. Ildstad ST, Tollerud DJ, Weiss RG, Ryan DP, McGowan MA, Martin LW. Duplications of the alimentary tract: clinical characteristics, preferred treatment, and associated malformations. Ann Surg. 1988;208(2):184-189. 
6. Yamasaki A, Onishi H, Yamamoto H, et al. Asymptomatic adenocarcinoma arising from a gastric duplication cyst: a case report. Int J Surg Case Rep. 2016;25:16-20.

7. Kang HJ, Jang SJ, Park YS. Adenocarcinoma arising in gastric duplication cyst. Korean J Pathol. 2014;48(2):159-161.

8. Liu K, Lin X, Wu J, et al. Peritoneal metastatic adenocarcinoma possibly due to a gastric duplication cyst: a case report and literature review. BMC Gastroenterol. 2014;14:48.

9. Shin SY, Cho MY, Ryu H, et al. Adenocarcinoma originating from a completely isolated duplication cyst of the mesentery in an adult. Intest Res. 2014;12(4):328-332.

10. Blank G, Königsrainer A, Sipos B, Ladurner R. Adenocarcinoma arising in a cystic duplication of the small bowel: case report and review of literature. World J Surg Oncol. 2012;10:55.

11. Zheng J, Jing H. Adenocarcinoma arising from a gastric duplication cyst. Surg Oncol. 2012;21:e97-e101.

12. Jiang W, Zhang B, Fu Y, et al. Gastric duplication cyst lined by pseudostratified columnar ciliated epithelium: a case report and literature review. J Zhejiang Univ Sci B. 2011;12(1):28-31.

13. Fukumoto K, Suzuki S, Sakaguchi T, et al. Adenocarcinoma arising from gastric duplication: a case report with literature review. Clin J Gastroenterol. 2008;1(4):148-152.

14. Kuraoka K, Nakayama H, Kagawa T, Ichikawa T, Yasui W. Adenocarcinoma arising from a gastric duplication cyst with invasion to the stomach: a case report with literature review. J Clin Pathol. 2004;57(4):428-431.

15. Coit DG, Mies C. Adenocarcinoma arising within a gastric duplication cyst. J Surg Oncol. 1992;50(4):274-277.
16. Mayo HW, McKee EE, Anderson RM. Carcinoma arising in reduplication of the stomach (gastrogenous cyst): a case report. Ann Surg. 1955;141(4): $550-555$.

17. Treiger M, Rubens J, Chindler J, et al. Stomach duplication. Report of a 2nd case in literature complicated by a peptic ulcer and malignant neoplasms (in Portuguese). Hosp Rio J. 1969;75:1-10.

18. Ishikawa M, Samejima N, Matsushita M, et al. A case of early cancer of the duplicated stomach accompanied with gastric cancer (in Japanese). Jpn J Gastroenterol Surg. 1988;21:2148-2151.

19. Mamiya N, Karasawa Y, Kojima N, Takemoto T, Kondoh N, Kasai S. A case of gastric duplication cyst containing papillary adenocarcinoma (in Japanese). Jpn J Gastroenterol. 1996;93(1):34-38.

20. Sutcliffe J, Munden M. Sonographic diagnosis of multiple gastric duplication cysts causing gastric outlet obstruction in a pediatric patient. J Ultrasound Med. 2006;25(9):1223-1226.

21. Kim DH, Kim JS, Nam ES, Shin HS. Foregut duplication cyst of the stomach. Pathol Int. 2000;50(2):142-145.

22. Hartnick CJ, Barth WH Jr, Coté CJ, Albrecht MA, Grant PE, Geyer JT. Case records of the Massachusetts General Hospital. Case 7-2009. A pregnant woman with a large mass in the fetal oral cavity. $N$ Engl J Med. 2009;360(9):913-921.

23. Maeda H, Okabayashi T, Nishimori I, et al. Diagnostic challenge to distinguish gastric duplication cyst from pancreatic cystic lesions in adult. Intern Med. 2007;46(14):1101-1104.

24. Scatizzi M, Calistri M, Feroci F, et al. Gastric duplication cyst in an adult: case report. In Vivo. 2005;19(6):975-978.
International Medical Case Reports Journal

\section{Publish your work in this journal}

The International Medical Case Reports Journal is an international, peer-reviewed open-access journal publishing original case reports from all medical specialties. Previously unpublished medical posters are also accepted relating to any area of clinical or preclinical science. Submissions should not normally exceed 2,000 words or
Dovepress

4 published pages including figures, diagrams and references. The manuscript management system is completely online and includes a very quick and fair peer-review system, which is all easy to use. Visit http://www.dovepress.com/testimonials.php to read real quotes from published authors.

Submit your manuscript here: https://www.dovepress.com/international-medical-case-reports-journal-journal 